\title{
PALESTINIAN REFUGEE CAMPS: FROM SHELTER TO HABITAT
}

\author{
Henri Rueff and Alain Viaro*
}

Palestinian refugees registered with UNRWA and their housing conditions are officially characterized by a "temporary status", a situation which has lasted the past sixty years. This article explores this time-paradox by focusing on the host governments' and UNRWA's policies affecting the refugees' housing conditions. After having reviewed available literature, this contribution analyses the current housing situation. Drawing on data from a recent survey, the authors provide insights on areas where intervention is needed. In all UNRWA's fields of operation, overcrowding, lack of public spaces, humidity and structural defects are the main sources of housing discomfort that camp refugees endure. Host countries' restrictions as well as the incapacity or unwillingness of larger urban municipalities to incorporate refugee camps in their master plans are among the main obstacles to the refugees' housing development. Rehabilitation and self-help re-housing programs may offer substantial incentives for housing improvement. The success of such programs depends, among several factors, on the host governments' good will to provide UNRWA with authorizations, financial support, and land, as well as on the capacity of involving the refugee communities in projects' planning and implementation.

\section{Introduction}

Housing conditions affect the physical and psychological health of dwellers, which is especially true in the case of underprivileged communities with unstable livelihoods and unsettled status. Habitat in Palestinian refugee camps has evolved from the tents and one-room shelters provided sixty years ago to vertical and horizontal sprawls of houses built according to the dwellers' needs and assets. The often overcrowded camps have been built on limited perimeters of land and are generally difficult to extend. Thus, most host governments have tolerated additional floors, which have been added to the houses to accommodate growing families.

The term "shelter" usually indicates a temporary or emergency form of dwelling, while "habitat" denotes a more durable form of housing. In the

\footnotetext{
* Alain Viaro is an architect and town planner, (retired) Senior lecturer at the former IUED (Graduate Institute of Development Studies) of Geneva. Henri Rueff is researcher at the Centre for Development and Environment, Institute of Geography, University of Bern.
}

Refugee Survey Quarterly, Vol. 28, Nos $2 \& 3$ (C) UNHCR [2010]. All rights reserved.

For Permissions, please email: journals.permissions@oxfordjournals.org

DOI:10.1093/rsq/hdp041 
aftermath of the two main waves of forced displacement in 1948 and 1967, Palestinian refugees were sheltered in tents, barracks, and other light-weight housing types. Later on, refugees were accommodated in single-room units made of concrete. Since then, different types of "habitat" evolved, ranging from the unregulated extension of the one-room unit to more specific development plans for the construction of houses according to the policies of the host countries. In this sense, the habitat can be defined as "the place of living, the people living in a place, and the interactions between both." 1

The patterns of house occupancy inside camps often mirror refugees' social organization: relatives and neighbours who were living in the same villages before the exile have tended to recreate the community. In all cases, the meanings associated with the house keep a central role:

The house (al dar) comprises the fundamental framework, which surrounds family life and separates the private domestic realm from the public domain. The house is a physical representation of the family which resides within it, and the importance of the house reflects the prominence of family within Palestinian society. It is an indicator of its status and the permanence of transience of its anchoring to the local community. It also signals some of the central values and priorities within the society. ${ }^{2}$

This definition is, by the way, very close to the notion of "house" in the traditional Palestinian rural society prior to the 1948 war:

Members of each hamûleh (patrilineal descent group) lived in a group of adjacent houses connected by one or more courtyards. The houses were grouped round the courtyards in different ways depending on closeness to the family patriarch. Sons would move out of the family house after they married and would establish separate domestic units adjacent to those of their fathers' often sharing the same courtyard. ${ }^{3}$

The inner meaning of "home" has also been emphasized in the context of Palestinian refugees living in camps. As M. Heiberg has shown for the occupied Palestinian territories $(\mathrm{oPt})$ in the early 1990s:

The house has gained an uncommon importance because people tend to spend a good deal more of their time within it. Moreover, many social activities traditionally enjoyed by Palestinians have ceased with the Intifada. ${ }^{4}$

For Palestinian refugees, the difference between "shelter" and "habitat/home/ house" is substantial. R. Sayigh, describing the situation of Palestinian refugees in Lebanon, has raised the difference between "home in a refugee camp" and

H. Jaber, "Genesis and transformation of habitat in refugee camps: Widhat Camp in Jordan", in R. Bocco (ed.), UNRWA, A History Within History, Proceedings of the 20-2 Dec. 1996 Workshop, Amman, CERMOC, 1997, 164.

2 M. Heiberg, "Housing", in M. Heiberg \& G. Ovensen (eds.), Palestinian Society in Gaza, West Bank and Arab Jerusalem. A survey of living conditions, Oslo, FAFO, Report 151, 1993, 81-98.

3 S. Amiry and V. Tamari, The Palestinian Village Home, London, British Museum, 1989.

4 Heiberg, "Housing", op. cit. These observations continued to be valid also during the second Intifada. 
"home in homeland", and between a shelter, which cannot be a "home" and the symbol of loss, the ultimate goal of struggle:

A home (beit) has implications of security and permanence that have been violated in Lebanon more than in the other 'host' countries. The Palestinian villager's 'beit' in Palestine was built to last forever... A 'beit' in the full sense would have to be found through return to Palestine, or with full civic right in Lebanon... The camp 'beit' has never become a replacement of 'home' in Palestine, even though rebuilding it, or making it more spacious or more 'respectable' have absorbed untold amounts of refugee labour and savings. 5

Beside the symbolic importance, the meanings and perceptions of "house/home" for the Palestinian exiles, many indicators show the hard conditions of refugees' housing in camps. Population growth has generally spurred the demand for services and increased the difficulties in meeting the housing needs, ${ }^{6}$ while the status of Palestinian refugees in the host countries has officially remained "temporary" for the past sixty years. ${ }^{7}$

A number of research questions can therefore be raised: which policies have been/are adopted by the United Nations Relief and Works Agency for Palestine Refugees in the Near East (UNRWA or the "Agency") for addressing this time-paradox? How did/do host countries' policies interfere with the housing conditions of Palestinian refugees? Given the highly heterogeneous housing conditions throughout the five fields of UNRWA operations, how did/do needs differ across these areas?

After a synthesis of the available literature on the topic, this article will present the housing condition of Palestinian camp refugees through data drawn from a 2005 survey covering the five UNRWA fields of operation. ${ }^{8}$ The authors will identify levels of satisfaction perceived by refugees and will provide insights on critical issues requiring intervention.

We posit that host governments play a central role in unlocking the critical housing situation in refugee camps, because they have the right to allocate land for house construction. In a complementary way, facilitating mobility, access to jobs, and social integration constitute key items of an overall policy aiming at increasing refugees' income and thus housing conditions. Should host

\footnotetext{
5 R. Sayigh, "A House is not a Home: Insecurity of Habitat for Palestinian Refugees in Lebanon", in House: Loss, Refuge and Belonging, Conference Report 16-18 Sep. 2004, Trondheim, Norway, Forced Migration Review Supplement.

6 L. Blome Jacobsen, Finding Means: Socioeconomic Conditions of Palestinian Refugees in Jordan, Lebanon, Syria, West Bank and Gaza, Oslo, FAFO, Report 427, 2003.

See the contribution of J. Al-Husseini and R. Bocco in this volume.

8 The Graduate Institute of Development Studies of Geneva (IUED) and the Catholic University of Louvain were contracted by UNRWA in 2004 to conduct a study on the living conditions of the Palestinian refugees registered with UNRWA in its five fields of operation. The data collection phase took place during the summer of 2005 and a team of experts produced thematic reports during 2006-7. H. Rueff and A. Viaro wrote the chapter on habitat in 2007. A synthesis report was released the same year: R. Bocco, M. Brunner, J. Husseini. F. Lapeyre, E. Zureik, The Living Conditions of the Palestine Refugees: A Synthesis Report, UNRWAIUED/UCL Survey, Geneva and Louvain-la-Neuve, 2007.
} 
governments take major steps to improve the refugees' living and housing conditions, these decisions would not be disassociated from the aid agencies' role in providing assistance and financial resources.

We further argue that another essential step in the improvement of Palestinian refugee housing is the refugees' participation in development projects through community-based organizations. Past experiences in designing and constructing low-cost but adequate housing have proved efficient. ${ }^{9}$ These experiences have also shown the importance of the dwellers' inputs for optimal planning. ${ }^{10}$

\section{The evolution of the housing conditions of the Palestinian refugees}

Literature on the housing conditions in the camps during the first forty years of UNRWA activity is rather scanty. Until the early 1990s, apart from information available in a few reports, housing does not seem to have attracted the attention of many social science researchers. It was actually the signature of the Declaration of Principles in 1993 and the Oslo Peace Process that furthered systematic data collection and publication. FAFO, a Norwegian research institute, has regularly produced refugee surveys during the last two decades. ${ }^{11}$ Its quantitative studies cover a wide range of issues, such as demography, labour market, health, education, and the situation of children and women. In most FAFO reports, a specific chapter on housing conditions and the broader housing environment is included. The data collected usually include habitat types, building materials, occupation patterns, crowding within households, access to sanitation, water networks, nuisance from outdoor environment, garbage collection, sewerage, electricity connection, and availability of amenities. ${ }^{12}$

9 An example of a successful housing and neighbourhood development to look at is the Orangi Pilot Project. This Pakistani NGO has conducted large-scale and participative housing development projects in the squatter neighbourhood of Orangi in Karachi, Pakistan. See http://www.oppinstitutions.org (last accessed 27th November 2009).

10 The contribution of S. Hanafi and P. Misselwitz to this volume also deals with the Palestinian internal political debate related to the right of return and the "camp improvement taboo".

11 Following the Madrid Peace Conference in the fall of 1991, several multilateral working groups to accompany negotiations between Israel and the PLO were set by the international community. One of them, the "Refugee Working Group" (RWG) was created in May 1992 and was lead by Canada. Being part of the RWG, Norway offered to take care of the database on the Palestinian refugees and FAFO, established in 1983, became the main data producer on the living conditions of refugees in the five fields of UNRWA operations. See, S. Tamari, Palestinian Refugee Negotiations. From Madrid to Oslo II, Washington D.C., Institute for Palestine Studies, 1996.

12 M. Arneberg, "Housing Conditions", in M. Arneberg, Living Conditions among Palestinian Refugees and Displaced in Jordan, Oslo, FAFO, Report 237, 1997, 25-28; L. Blome Jacobsen and A. Khalidi, "Housing and Environment", in O. Fr. Ugland (ed.), Difficult Past, Uncertain Future: Living Conditions among Palestinian Refugees in Camps and Gatherings in Lebanon, Oslo, FAFO, 2003, 183-208; L. Blome Jacobsen, The Material and Social Infrastructure and Environmental Conditions of Refugee Camps in Syria, UNRWA Donors' Conference on the Humanitarian Needs of Palestinian Refugees, Geneva, June 2004; L. Blome Jacobsen, The Material and Social Infrastructure and Environmental Conditions of Refugee Camps in Lebanon, UNRWA Donors' Conference on the Humanitarian Needs of Palestinian Refugees, Geneva, June 2004; L. Blome Jacobsen, "Housing and Infrastructure", in A. Tiltnes (ed.), Palestinian Refugees in Syria: Human Capital, Economic Resources and Living Conditions, Oslo, FAFO, Report 514, 2006, 31-51; S. Gilen, 
From the mid-1990s onwards, a number of studies on refugee camps' housing conditions by geographers, economists, sociologists, and anthropologists have been published mainly in English and French. Most case studies have focused on Jordan, Lebanon and the oPt; research initiatives on Syria are almost non-existent.

Camps in Jordan, mostly around Amman, have been the subjects of numerous studies. A first survey in 1987-88 already showed that:

Housing conditions in camps and their fringe areas were generally much poorer than in the rest of the city... Many units are characterized by problems resulting from poor construction, inadequate ventilation and dampness and low levels of maintenance. Whole areas suffer from very high densities of development, with each crudely constructed concrete unit tightly packed against its neighbours ... Blocks of houses present a continuous frontage of house walls onto the unmade street with house extensions often encroaching onto space once reserved for roads or other public use. ${ }^{13}$

This description corresponds to that of informal settlements elsewhere in Jordan ${ }^{14}$ and to that provided by other researchers who studied refugee camps in Jordan during the 1990 s. ${ }^{15}$ Interestingly, similar results were found in a recent survey conducted in 2005. ${ }^{16}$

In Lebanon, J. Sfeir and M. K. Doraï in particular have detailed the history of the creation and development of camps, ${ }^{17}$ while other authors have privileged the analysis of camps as spaces of violence. ${ }^{18}$ A more recent and in-depth

A. Hovdenak, R. Maktabi, J. Pedersen, D. Tuastad, Finding Ways. Palestinian coping strategies in changing environments, Oslo, FAFO, Report 177, 1994; M. Khawaja and A. Tiltnes, "Housing and Infrastructure", in M. Khawaja and A. Tiltnes (eds.), On the Margins: Migration and Living Conditions of Palestinian Camp Refugees in Jordan, Oslo, FAFO, Report 375, 2002, 125-39; L. J. Stokke, "Housing Conditions", in J. Pedersen, S. Randall and M. Khawaja (eds.), Growing Fast: the Palestinian Population in the West Bank and Gaza Strip, Oslo, FAFO, Report 353, 2001, 171-8; A. Tiltnes, "Housing and Environment", in A. Tiltnes, Falling Behind: a Brief on the Living Conditions of Palestinian Refugees in Lebanon, Oslo, FAFO, Report 464, 2005, 29-39; A Tiltnes, "Housing and Infrastructure", A. Tiltnes, Keeping up. A brief on the Living Conditions of Palestinian Refugees in Syria, Oslo, FAFO, Report 20013, 2007, 19-25.

13 M. Abu Helwa \& B. Birch, "The demography and housing conditions of Palestinian Refugees in and around the camps in Amman", Journal of Refugee Studies, 6(4), 1993, 403-13.

14 J. I. Al Daly, Informal Settlements in Jordan. Upgrading approaches adopted and lessons learned, Lund, 2000 (http://www.hdm.Ith.se/training/postgrad/Papers/2000/10_ad.2000.pdf) (last accessed 31st March 2009); D. Drury \& T. M. Abu-Sharar, "Housing and Infrastructure", in J. Hanssen-Bauer, J. Pedersen, A. Tiltnes (eds.), Jordanian Society. Living Conditions in the Hashemite Kingdom of Jordan, Oslo, FAFO, Report 253, 1998, 97-117.

15 B. Destremau, "L'espace du camp et la reproduction du provisoire: les camps de réfugiés palestiniens de Widhat et Jabal Hussein à Amman”, in R. Bocco \& M.-R. Djalili (eds), Moyen-Orient: Migrations, democratisations, mediations, Paris, PUF, 1994, 83-98; H. Jaber, "Le camp de Wihdât, entre norme et transgression", Revue d'etudes palestiniennes, 8, 1996, 37-48.

16 H. Rueff and A. Viaro, The Housing Conditions of the Palestine Refugees, IUED-UCL/UNRWA Near East Project, 2007. See also: Bocco et al., The Living Conditions of the Palestine Refugees, op. cit.

17 J. Sfeir, "Du provisoire au permanent: les débuts de l'installation des réfugiés au Liban, 1948-1951", in The MIT Electronic Journal of Middle East Studies, 1, 2001 (http://web.mit.edu/cis/www/mitcjmes/) (last accessed 31st March 2009); J. Sfeir, L'exil palestinien au Liban: le temps des origines (1947-1952), Paris \& Beyrouth, IFPO, Karthala, 2008; M. K. Doraï, Les réfugiés palestiniens au Liban: une géographie de l'exil, Paris, CNRS, 2006.

18 Z. Halabi, "Exclusion and identity in Lebanon's Palestinian refugees camps: a story of sustained conflicts (Chatila)", Environment and urbanization, 6(2), 2004, 39-48; S. Hanafi, "Palestinian Refugees Camps in 
sociological analysis of the refugees' living conditions has been conducted in the small camp of Shu'afat, in East Jerusalem. ${ }^{19}$ The study also shows how the construction of the security wall has had a disruptive impact on the daily life of its dwellers and their housing conditions. ${ }^{20}$

Despite rather abundant literature on the history, development, and political sociology of camps, few studies have thus explored the registered refugees' housing conditions.

\subsection{UNRWA housing policies: a historical overview}

The Agency has, over time, documented its initiatives in the field of housing availability and improvement through a set of technical reports, as well as in the yearly "Report of the Commissioner-General of UNRWA to the UN General Assembly".

From 1950 until today, the armed conflicts and the unstable political climate in the Near East have by and large shaped the trends of UNRWA policies and programs. In spite of the operational difficulties, the Agency has developed the ability to intervene in two main ways. On the one side, it has set up temporary shelters in situations of emergency; on the other side, it has insured a long-term management of infrastructures and has sought their improvement. ${ }^{21}$

Following the 1948 war, and before settling in camps, most Palestinian refugees had moved in a relatively unregulated manner. In the early 1950s, the setting up of camps in host countries constituted UNRWA's first phase of activity. The Agency's policy was based on renting public or privately owned grounds, within strictly demarcated areas allocated by host countries. Camps were erected next to cities and along roads to ensure access of goods and building material. Initially, camps were made of tents and shared sanitary facilities. In some cases, military barracks or former refugee camps (like the Armenian refugee camps in Lebanon) were also used. ${ }^{22}$

Throughout the 1950s, UNRWA replaced tents with more durable shelters. Each family was given a plot of $80-100 \mathrm{~m}^{2}$ on which a "core unit" with one 12 $\mathrm{m}^{2}$ room and sanitary services was built. The walls were made of bricks and cement with asbestos roofing. A family of four to five members received the "core unit" and a family of six to eight members received two rooms. ${ }^{23}$ Gradually, refugees extended their shelter with new rooms in mud or concrete

Lebanon as a Space of Exception", in "Palestiniens en/hors camps", Asylon(s), 5, Sept. 2008 (http://www .reseau-terra.eu/rubrique147.html) (last accessed 27th November 2009).

19 S. Bulle, "Entre guerre et paix: chronique d'une condition urbaine moderne. Les citadins de Jerusalem-Est", in I. Berry-Cherkaoui, A. Deboulet, L. Roulleau-Berger (eds), Apprentissage des villes internationales, Paris, La Découverte, 2007.

20 S. Bulle, "Domestiquer son environnement. Une approche pragmatiste d'un territoire confiné: le camp de réfugiés de Shu'faat à Jérusalem”, in Terrains d'Asile, Asylon(s), 2, Nov. 2007 (http://www.reseau-terra.eu/ article672.html) (last accessed 27th November 2009).

21 UNRWA, History of UNRWA Initiatives in Shelter Rehabilitation, Camp Infrastructure Development and Housing, Policy Analysis Unit, UNRWA Headquarters, Gaza, Mar. 2004.

22 Sfeir, "Du provisoire au permanent", op. cit.; Sfeir, L'exil palestinien au Liban, op. cit.; Doraï, Les réfugiés palestiniens au Liban, op.cit.

23 Destremau, "L'espace du camp et la reproduction du provisoire", op. cit. 
to fit the needs of their growing families. Boundary fences started to appear, defining pathways between the "properties". To underline the temporary character of the houses, no additional floors were allowed. When they had built on the whole plot, the occupants expanded it beyond the pathways, producing a spider network of narrow paths, dead-end alleys, and irregularly shaped houses.

Ultimately, and even if formally prohibited by the local authorities, there was no choice but to opt for the vertical expansion of the camps. Extra floors began to be built on top of existing units, resulting in multi-level housing accommodating extended families. ${ }^{24}$

While this process intensified after the 1967 war, new emergency camps made of tents were set up. They were later replaced by pre-fabricated shelters and finally by more durable structures built by the refugees themselves. By the end of the 1960s, UNRWA had also expanded its activities to the building of schools, hospitals, warehouses and other service buildings. These buildings were constructed either within the camps, if sufficient space was available, or outside, in neighbouring areas. The 1970s and the 1980s were marked by the recurrent outbreak of local and international armed conflicts, and, consequently, the partial or entire destruction of camps. Additional measures taken by the host countries, other UN agencies, and local aid organizations complemented UNRWA's efforts in repairing and improving camps.

In addition to reconstruction programs in the aftermath of conflicts, UNRWA provided assistance to refugees whose shelter and living conditions did not meet minimally accepted housing standards. In principle, the rehabilitation of individual shelters was restricted to "hardship cases", ${ }^{25}$ but ultimately all refugees benefited from large-scale upgrading projects. More recently, and in cooperation with the Syrian Government, UNRWA has embarked on the first comprehensive reconstruction project for the Neirab and Ein el-Tal camps near Aleppo. ${ }^{26}$ In Lebanon, the Agency is presently carrying out a project for the reconstruction of the Nahr el-Bared camp. ${ }^{27}$

\subsection{Managing uncertainty and ambiguities}

The status of the land on which camps were built is a key feature to understanding the complex relationship Palestinian refugees have with the host countries and its consequences on the housing conditions. UNRWA has deliberately been kept in the role of a tenant in order to prevent refugees registered with the Agency from acquiring any form of permanent status. Initially, this temporary

24 Jaber, "Genesis and Transformation of Habitat in Refugee Camps", op. cit.

25 UNRWA, Shelter Rehabilitation Programme for Vulnerable Palestine Refugees: Historical Background and Evolution, Engineering \& Construction Services Division, UNRWA Headquarters, Amman, Mar. 2004; Shelter Rehabilitation for Special Hardship Families: Current Practices, Challenges and Issues, Amman, Mar. 2004.

26 UNRWA, Neirab Rehabilitation Project and Development of Ein el-Tal Camp, Field office SAR, Aleppo, April 2003; Neirab Rehabilitation Project. Project Briefing, Aleppo, Feb. 2004; Neirab Rehabilitation Project Phase One. Development of Ein el-Tal, Damascus, April 2005.

27 UNRWA, Nahr el-Bared Palestine Refugee Camp. UNRWA Relief, Recovery and Reconstruction Framework 2008-2011, Lebanon Field Office, May 2008. 
status deflated the income of landlords who rented their land to UNRWA. Indeed, the land rented to UNRWA was previously located in rural areas or in the outskirts of cities. Thus, back then, the land rented for camps was of low value. But after sixty years, most camps became embedded within cities and the value of the land they lay on has substantially increased. ${ }^{28}$ Landlords have therefore progressively voiced their dissatisfaction over renting out their land to UNRWA, which has kept prices much lower than what could have been asked, had the land been developed for other projects but camps.

The "temporary" status of camps, coupled with the lack of extension possibilities due to dense urban surroundings, has rendered the rehabilitation of camps a difficult task. ${ }^{29}$ Camps usually do not appear on official maps and do not receive municipal services, although they are physically integrated within cities. ${ }^{30}$ Managed by the UN, often with the help of non-governmental organizations (NGOs), they have in some ways evolved independently. These international organizations, operating at a humanitarian level, share the provision of services for tens of thousands of inhabitants in terms of municipality services, food, education, and health. ${ }^{31}$

However, at the municipality level, authorities often lack the means to elaborate coherent urban master plans for areas, which are out of their control, sometimes jeopardizing the future development of the cities. Moreover, camp refugees do not pay property, habitation, equipment, shop or business taxes, which constitute the usual source of municipalities financing. ${ }^{32}$

M. Agier ${ }^{33}$ explains how the assistance brought to refugees by political groups and NGOs is, in part, the reason why camps are often maintained in a system of territorial and legal marginalization. The role played by these organizations is that of a municipal council without democratic legitimacy. Though this is not always the case with refugee camps administered by UNRWA, as the inhabitants are consulted with and the Palestine Liberation Organization is their political representative, nevertheless, marginalizing the refugees feeds their dream of a possible return.

M. K. Doraï has insisted on the difference between "refugees in camps" and "urban refugees", suggesting that refugees are fully part of the environment of the cities and that they develop strategies to take advantage of their status. ${ }^{34}$

28 Destremau ("L'espace du camp et la reproduction du provisoire", op. cit.) showed that the market value of camps in Amman was 100 to 400 times higher than the value paid by UNRWA as tenant.

29 Al-Husseini, "Les camps de réfugiés palestiniens au Proche-Orient, entre norme du droit au retour et intégration socio-économique”, Aug. 2008 (http://www.terra.rezo.net/article799.html) (last accessed 31st March 2009).

30 Destremau, "L'espace du camp et la reproduction du provisoire", op. cit.

31 M. Agier, "De nouvelles villes: les camps de réfugiés", in Les Annales de la recherche urbaine, 91, 2001, 128-136; Gérer les indésirables: Des camps de réfugiés au gouvernement humanitaire, Paris, Flammarion, 2008.

32 Jaber, "Genesis and Transformation of Habitat in Refugee Camps", op. cit.

33 Agier, "De nouvelles villes", op.cit.

34 M. K. Doraï, "Du camp à la ville. Migrations, mobilités et pratiques spatiales dans les camps de réfugiés palestiniens au Liban", in "Palestiniens en/hors camps, formes sociales, pratiques des interstices", Asylon(s), 5 , Sept. 2008 (http://www.reseau-terra.eu/article802.html) (last accessed 27th November 2009); "From Camp Dwellers to Urban Refugees? Urbanization and Marginalization of Refugee Camps in Lebanon", 2008 
In the camp of Mar Elias in Lebanon, for example, many shops have been opened by refugees who do not live in the camp, but took advantage of the lower prices in the camps for starting their businesses. The densification of the camps, especially after more floors were added to the houses, strengthened the ties between the inhabitants in the cities and refugees living in the camps embedded in these cities. This has resulted in an increase of exchanges, especially on the labour market, while camps and informal gatherings have increasingly integrated the economic activity of the urban environment.

The works of B. Destremau and H. Jaber in Jordan have highlighted that, although the official tenure of the camps has remained "frozen", this has not prevented the development of an informal and rather dynamic real estate market, in which houses and shops are sold along with the exchange of plots to allow families to reunite within camps. ${ }^{35}$

This "lasting temporary situation" makes household planning for the longterm a hard task. In some cases, deciding to move outside camps may imply losing UNRWA's assistance in terms of food, schooling, health, and employment.

Planning at the camp level is also restricted with much of the facilities remaining provisional and unfit to provide adequate housing to growing refugee communities. It is also not easy to envisage the destruction of old dwellings for the construction of larger and neater buildings. This would require the re-housing of refugees and important funding.

UNRWA's policy of providing special assistance to hardship cases for housing improvement confirms that the poorest and most vulnerable among the refugee community endure high levels of housing discomfort in an insalubrious environment.

As we will show in the next section, common sources of discomfort are the closeness of houses, noise pollution, poor cooling and heating capacity of the houses due to the use of inadequate construction material, poor ventilation and the stagnation of smoke inside the houses.

The UNRWA policy in recent years is an attempt to shift from the improvement of shelters to comprehensive camp rehabilitation or even reconstruction. This new approach raises two questions. First, refugees have to express their willingness to be re-housed while all their rights remain granted. Second, host governments should agree with the principle of the extension or rebuilding of new housing units by UNRWA. The plans should be integrated into local urban master plans, in order to integrate the new neighbourhoods into the existing urban patterns. The construction of infrastructures such as sewers, water delivery and roads should be carried out by the municipalities or coordinated with them.

(www.mshs.univ-poitiers.fr/migrinter/membre/dorai_colloques_2008.pdf) (last accessed 27th November 2009).

35 B. Destremau, "Les camps de réfugiés palestiniens ou la double identité territoriale: le cas d'Amman", Les Cahiers d'URBAMA, 11, 1995, 5-56; B. Destrmau, "Les camps de réfugiés palestiniens et la ville, entre enclave et quartier", in J. Hannoyer \& S. Shami (eds.), Amman. Ville et Société, Amman, CERMOC, 1996, 527-552; Jaber, "Genesis and Transformation of Habitat in Refugee Camps", op. cit. 
The re-housing of refugees living in the Neirab and Ein el Tal camps in Syria illustrates the latter case. The project involved the move of 5,000 families from Neirab to the nearby camp of Ein el Tal in 2002. The new 300 dwellings were constructed out of light stone with two or three floors and three to four rooms per household with landscaped communal areas.

The Syrian Government and the authorities of the Aleppo Governorate provided the infrastructure, extending the main municipal sewerage network to the camp entrance. They asphalted the main roads leading to the camp and brought street lightning to the area. ${ }^{36}$ From the onset, UNRWA has actively engaged the residents of Neirab in the planning and development of the project. $^{37}$

Another comprehensive reconstruction project occurred in the camp of Nahr el Bared in Lebanon. ${ }^{38}$ The siege and destruction of the camp in 2007 left thousands of Palestine refugee families (5,449 families) homeless and in dire poverty. The majority of the families who fled the conflict sought refuge in and around the Beddawi refugee camp in the outskirts of Tripoli, nearly doubling this camp's population over-night.

UNRWA is currently working in coordination with the refugee community and the Government of Lebanon for the reconstruction of the Nahr el Bared refugee camp which should be completed by the end of 2011. This change of direction in UNRWA's strategies results from the 2004 Geneva Conference, where the "right to live in appropriate living conditions" was differentiated from the "right of return". 39

\section{The present housing conditions in the five UNRWA fields of operation}

UNRWA has responded to the deteriorating living conditions in the camps by setting standards and developing guidelines. Housing standards have been established in terms of plot size, area for courtyards and height of walls to ensure privacy, number of rooms per person, surface occupancy, provision for the expansion of residences, and number of sanitary facilities. ${ }^{40}$ Host governments have undertaken construction of heavy infrastructure, such as the sewerage networks, while UNRWA has installed sewerage systems and water networks in the worst-off camps when host governments have failed to do so.

36 UNRWA, Neirab Rehabilitation Project. Project Briefing, Aleppo, February 2004; L. Takkenberg and H. Mukhles, "Neirab Rehabilitation Project" (http://www.fmreview.org/textOnlyContent/FMR/22/ 28.htm) (last accessed 27th November 2009).

37 Y. Bouagga, "Comment être Palestinien ? Observations sur la réhabilitation d'un camp par l'UNRWA en Syrie (Neirab)", TERRA-ed., Coll. Synthèses, 2006 (http://www.reseau-terra.eu/article445.html) (last accessed 27th November 2009).

38 UNRWA, Nahr el-Bared Palestine Refugee Camp, op. cit.

39 See, the contribution of Ph. Misselwitz and S. Hanafi in this volume.

40 UNRWA, Planning, Design and Community Participation for Camp Upgrading and Rehousing Projects, Engineering \& Construction Services Division, UNRWA Headquarters, Amman, Mar. 2004; J. Price, Shelter Rehabilitation. Comparative Study. Design, Specification and Standards, Preliminary Report 2, Amman, Mar. 2006. 
Several differences influence housing conditions in the five UNRWA fields. First, the sharp climatic gradient, from the mountainous areas and plains in northern Lebanon to the semi-arid conditions in the North-West of Jordan and in the West Bank, results in different needs in terms of construction material and housing design. Construction material properties are another important factor affecting housing comfort, in terms of passive cooling and heating. Second, housing conditions in areas under UNRWA's operational mandate may differ between refugees living in or outside camps. Actually, most refugees live outside camps: 79 per cent in Jordan, 67 per cent in Syria and in the West Bank, 58 per cent in Gaza and 49 per cent in Lebanon. Third, the legal status of refugees in host countries affects mobility, job opportunities and thus living conditions. ${ }^{41}$

\subsection{The 2005 survey}

The data and statistical analysis presented in this chapter is derived from the IUED-UCL/UNRWA survey conducted in 2005. It encompassed sixty-seven questions answered by a sample of 10,000 respondents, representing the 4,125,000 Palestinian refugees registered with UNRWA. Twelve questions from the survey contained 119 housing-related variables. ${ }^{42}$ The methodology used in this report favours a two-scaled approach to analyse housing issues. A first scale of analysis compares the camp/non-camp differences in housing conditions within locations. A second scale of analysis compares the housing conditions between different locations. ${ }^{43}$

Housing issues relating to Palestinian refugees can be grouped into four categories: safety and health, comfort, public spaces, and mobility. Safety and health-related issues cover indoor and outdoor environmental conditions. The use of some materials for the construction of unplanned or improvised houses enhances structural defects, which puts dwellers at risk. The kinds of construction materials used also influence passive cooling and heating of houses that affect indoor temperatures and, indirectly, health. The release of toxic fumes from the combustion of some fuels used for heating and cooking can cause respiratory problems, as do the lack of ventilation and the presence of humidity.

Comfort-related issues include crowding of houses and camp density, both of which also affect privacy. The number and kinds of appliances available may, to some extent, indicate levels of comfort and, indirectly, a household's income. Recreational areas and green spaces compensate for the limited amount of other public spaces and the narrowness of the streets. Issues related to mobility and

41 Op cit., fn. 8.

42 See H. Rueff and A. Viaro, The Housing Conditions of the Palestine Refugees, op.cit.; Bocco et al., The Living Conditions of the Palestine Refugees, op.cit.

43 A previous report also suggested that this scale of analysis is systematic and well balanced. See, UNRWA, "Who are the refugees? Social, economic and legal conditions", paper presented at the Stocktaking Conference on Palestinian Refugee Research, Ottawa, 2003. Consequently, in the IUED-UCL/UNRWA survey of 2005, local specificities were not considered. 
accessibility are important because they directly affect livelihoods (access to jobs and markets), education, and access to administrative offices. Finally, pavement of streets and roads, transportation networks, and refugees' status in host countries are factors that impede or ease mobility.

\subsection{Crowding in houses}

Adequate space for dwellers is an important housing right which contributes to a healthy living environment (preventing the spread of diseases) and privacy. ${ }^{44}$ Yet, crowding within households is a major difficulty faced by most Palestinian refugees. ${ }^{45}$ Crowding is measured both by the occupancy per room and by the floor area per capita. FAFO suggests that the levels of house occupancy are considered adequate when not more than two persons share a room. ${ }^{46}$

The United Nations High Commissioner for Refugees (UNHCR) has set a norm for the area occupancy per person in shelters to at least $3.5 \mathrm{~m}^{2}$. In general, UNRWA sets its assistance criteria for shelter rehabilitation and re-housing at two persons per room per housing unit. ${ }^{47}$ For large households (seven persons or more), the density may occasionally be more than two persons per room (living rooms and bedrooms) but should not exceed three persons. According to UNRWA's housing norms, normal floor area occupancy should not be less than seven square meters per person excluding bathroom $\left(6 \mathrm{~m}^{2}\right)$, kitchen $\left(10 \mathrm{~m}^{2}\right)$, a circulation space of 25 per cent over the net area, and a staircase space allowance estimated at $4 \mathrm{~m}^{2}$.

The survey results show that all locations and sites experience considerable overcrowding, both in terms of area per person and number of persons per room. The situation is particularly critical in camps in Jordan (70 per cent), Syria (73 per cent), and Lebanon (71 per cent). Unexpectedly, camps in the West Bank and Gaza, although highly overcrowded, are nevertheless better off (Gaza, 46 per cent and West Bank, 49 per cent). There are fewer discrepancies between the incidence of overcrowding in camps and non-camps in the West Bank and Gaza, while overcrowding is observed far more often inside camps than outside them in the three other locations. The largest gap in terms of overcrowding between those living in camps and those living outside can be found in Lebanon. There is less overcrowding of refugees living outside camps in Lebanon than in any other location. Camp refugees in Syria are the most exposed to overcrowding. Except for Syria, these findings are in line with another report released in $2008 .^{48}$

S. Leckie, "Housing Rights", in UNDP, Human Development Report 2000, New York, UN, 2000.

L. Blome Jacobsen \& Khalidi, "Housing and Environment", op. cit.

L. Blome Jacobsen, Finding Means, op. cit.

J. Price, "Shelter Rehabilitation: Comparative study", Preliminary report 2: Design, Specification and Standards, UNRWA Headquarters, Amman, Mar. 2006.

48 BADIL, "Survey of Palestinian Refugees and Internally Displaced Persons 2006-2007", Bethlehem, 2008. 


\subsection{Population density in camps}

Urban patterns and integration of camps into larger cities influence the population density of camps. Other factors contributing to differences in density by location are land legislation and the status of refugees in the host country. Restrictions imposed on mobility and re-housing opportunities outside camps, coupled with less land provided for the expansion of camps are additional factors.

When compared to the ten most densely populated administrative units in the world, the population density of registered refugees in camps clearly shows critical levels, regardless of location.

It is in the camps of Lebanon that refugees endure higher density (over 100,000 registered inhabitants in most camps), while the standard deviation remains comparable to that of Jordan, Gaza, and the West Bank. The West Bank and Jordan have the lowest average density. These figures do not include the total inhabitants (that is, non-registered refugees or non-refugees), which may, in some cases, seriously increase the population density in camps. Systematic censuses of camp dwellers in the five UNRWA fields are to date unavailable. Often, highly densely populated camps are relatively small camps. Indeed, while Camp no.1 and Beit Jibreen in the West Bank show a population density of over 100,000 inhabitants per square kilometre, their population of registered refugees does not exceed 7,000 inhabitants.

\subsection{Structural defects, house types, tenure and construction material}

UNRWA camps' managers do not supervise extensions of houses, and limit their interventions to recommendations. Refugees may not always receive adequate guidance for construction, or they may be reluctant to give up vertical extension of their houses, despite safety risks. ${ }^{49}$ UNRWA ensures maintenance and reconstruction of shelters for special hardship cases inside camps. Those living outside camps are given financial assistance for repairs. ${ }^{50}$

Structural defects in refugees' houses occur, due to frequently improvised constructions and recurrent vertical extensions to accommodate growing households. They may also result from the choice of material and the type of dwelling, and are exacerbated in war-torn areas exposed to demolition and shelling.

The highest proportions of refugees reporting defects in the living rooms and bedrooms of their houses are in Lebanon (48 per cent) and Jordan (37 per cent). It also shows large differences in terms of defects reported between those living in camps and outside camps ( 58 and 37 per cent, respectively, in Lebanon; 55 and 33 per cent in Jordan). Fewer refugees in Syria and Gaza reported structural defects than those in the other locations.

\footnotetext{
49 The extent of self-help in shelters, the design of shelters and of materials used and their standards is discussed in detail in: UNRWA, Shelter Rehabilitation: A Comparative Study, 2006.

50 Blome Jacobsen and Khalidi, "Housing and Environment", op. cit.
} 
A higher proportion of refugees living outside camps in Syria, the West Bank, and Gaza own their dwellings, compared with refugees in the other fields. More refugees living outside camps in Lebanon tend to rent their dwellings than those in the other locations (36 per cent rented, 50 per cent owned). Roughly one-third of refugees in Jordan reported renting their residence in camps (16 per cent) and outside camps (32 per cent).

Restrictions on obtaining citizenship and property may explain higher rentals in Lebanon. Ownership of residence is nevertheless controversial. The land allocated to camps is not owned by UNRWA and thus not owned by the refugees served by UNRWA in camps. However, an informal housing market within camps often exists. Refugees may move elsewhere while keeping their residential rights within the camp and "rent" or "sell" their dwellings. In Lebanon, the authorities regulate access of construction materials into camps to control the sprawl of houses and the development of an informal real estate market that is beyond their reach. Governments have also limited the allocation of land in order to control the extension of camps. Consequently, a critical crowding situation has arisen from the absence of construction projects to meet the needs of the growing population.

Except for refugees living outside camps in Lebanon and Jordan, individual houses are the main type of residence for refugees in all the locations. There are a lower proportion of extended family houses in Lebanon outside camps (11 per cent). Such houses are often more common in camps while apartments are more common outside camps. Tents are no longer used to shelter refugees.

A logistic regression ${ }^{51}$ with defects as the dependent variable was used. A value of 0 was given when respondents reported no structural defects, while a value of 1 was given when structural defects were reported. The effects of six independent variables were tested against defects. Income level (divided into five categories in the survey) is expected to influence the quality of construction. It has already been demonstrated that the location of residence has an effect on building quality. In the regression, location was tested against defects under the control of other variables. The variables, roofing material, outside walls material, type of residence and tenure, were tested in the regression for their expected effects.

Results show that the site of the residence (that is, camploutside camp) is the explanatory variable with the highest effect on defects in Jordan and Lebanon. In other locations, the effect of the residential site variable is attenuated by the stronger effect of other independent variables. For example, the effect of the roofing material variable is the same as that of residential site in Syria and Gaza. Roofing material has the strongest effect in the West Bank. Outside wall material seems to have a limited effect. Surprisingly, income level has less of a negative effect than expected, considering that those with greater financial resources should be able to afford better housing quality. Likewise, the tenure variable seems to have a limited effect on defects. Renting, owning or residential rights

51 All coefficients of the regression are available in Rueff and Viaro, The Housing Conditions of the Palestine Refugees, op. cit. 
granted by UNRWA does not influence the occurrence of structural defects, and thus the efforts incurred in residence maintenance according to tenure. The observed weakness of this variable can also be explained by the distribution of attributes between residential sites. In fact, a large proportion of refugees own their houses outside camps, while a large proportion of refugees have residential rights granted within camps. Theoretically, ownership within camps, and residential rights granted by UNRWA outside camps is not possible.

Construction materials used for outside walls vary by location, but not much by residential site (that is, camps/outside camps). Concrete and cement seem to be widely used in Lebanon and the West Bank, while bricks are the main construction material elsewhere. Clay is not used or is only marginally used. Wood is not used anywhere due to its cost, scarcity, and lack of thermal inertia in order to keep the Middle East houses cool in the summer and warm in the winter.

In general, the model appeared to be rather weak in all fields, meaning that there are other factors that can explain the occurrence of structural defects in dwellings. Further investigation should enable a more accurate assessment of what causes these structural defects in refugees' dwellings.

\subsection{Neighbourhood public spaces, green spaces, and recreation}

High population density puts increasing pressure on the availability of public spaces and green areas, and affects the width of streets. In camps more specifically, houses and private spaces have encroached on public ones, resulting in narrower streets due to the lack of land for expansion of the camps, often to the extent that in some streets two persons can barely pass each other. This situation also increases the need for recreational areas, since narrow streets are neither suitable play grounds for children, nor do they allow people to meet and gather. The provision of green spaces also adds to the betterment of landscapes in overbuilt neighbourhoods.

The level of satisfaction among the refugees with the distance between the houses differs greatly between refugees living in camps and outside camps. A large majority of refugees in camps expressed unsatisfactory levels of privacy in terms of distances between houses. Only 11 per cent of refugees living in camps in Jordan were satisfied, while those in camps in other locations were just slightly more satisfied (22 per cent in Syria, 13 per cent in Lebanon, 15 per cent in Gaza, and 16 per cent in the West Bank). In contrast, refugees living outside camps expressed greater satisfaction, though even they claimed there were privacy problems (52 per cent in Jordan, 40 per cent in Syria, 57 per cent in Lebanon, 41 per cent in Gaza, and 70 per cent in the West Bank). The contrast in levels of satisfaction between refugees in camps and outside camps further demonstrates the critical level of population density within camps.

The survey results suggest that recreational facilities or social activity centres are lacking for a large majority of refugees regardless of residence location and site. Refugees in the West Bank reported higher levels of satisfaction than 
those in other locations. Though better off, more than 50 per cent of refugees in the West Bank still reported that such facilities were non-existent in their neighbourhoods.

A large majority of refugees (up to 88 per cent of those living in camps in Lebanon) do not have green spaces in their neighbourhoods, regardless of site and residential location; refugees living outside camps appear to be slightly better off.

In general, the lack of extra space outside houses adds to the critical level of overcrowding described previously. Palestinian refugees expressed dissatisfaction in terms of lack of privacy between houses, which is made worse by the absence of public spaces in terms of recreational areas, social centres, and green spaces.

\subsection{Access, mobility, paved streets and transportation networks}

Housing rights require that the location of a residence must allow access to services such as economic centres, administrative facilities, and supplies. Mobility influences access to education and opportunities for work, and is thus essential to sustain livelihoods.

As previously mentioned, the status of refugees in the host countries may ease or hinder mobility. Their mobility is generally disrupted in war-torn areas and occupied territories. In the latter, there are increased risks in travelling and the destination is often unreachable. In the West Bank and Gaza, for example, efficient transportation networks and infrastructure exist, but the fencing and recurrent encircling of camps by the Israeli Defense Force can put a stop to refugees' mobility for undetermined lengths of time. Closures, curfews, check-points, imposed itineraries and roads or by-pass routes lengthen journeys and increase the uncertainty about reaching a destination.

Since 2001, Palestinians in the West Bank have not been allowed to commute between cities unless they have permissions from the Israeli authorities. Jobs or education are not considered valid reasons for acquiring authorization. Under such conditions, some local populations and refugees are unable to reach hospitals, universities, and administrative services. Keeping a daily job, following an educational program, maintaining contacts with relatives, or undertaking any other activity with such limited or uncertain mobility is obviously difficult, if not impossible.

Several questions in the survey hinted at problems related to levels of mobility. Transportation appeared to be marginal in the decision to drop out of educational programs. Indeed, less than 1 per cent of respondents stated that the lack of transportation motivated their decision to withdraw from their educational program, while up to 20 per cent evoked the need to help at home as the main motive. Furthermore, transportation is not perceived as the main hindrance to seeking jobs. Less than 1 per cent of respondents reported difficulties in reaching their place of work as the main hindrance. Unemployed respondents, who were not seeking jobs, evoked family objections and social restrictions instead of difficulties in reaching employment areas as a main reason. 
Also, few cited transportation problems as being the reason for their children's lack of involvement in extra-curricular activities. A lack of interest in those activities or the lack of activities tended to be the main explanation.

Nevertheless, students do not in general endure excessive commuting times. The largest number of pupils having the longest (most critical) commuting situation is found in Gaza. Indeed, it takes more than an hour for 20 per cent of Gaza children living outside camps to reach their schools. Elsewhere, 10 per cent or less of the school children take more than half an hour to commute to schools. In general, children living in camps have shorter commuting times to their schools

Refugees outside camps, except for Gaza, benefit from better paved roads than those living in camps. On an average, 43 per cent of households in camps do not have a fully paved road/street to access their houses (except for Gaza where the trend is reversed). This figure falls to 28 per cent for refugees living outside camps. Refugees within camps in Lebanon and Jordan, as well as those outside camps in Gaza, are worse off.

Camp refugees in Lebanon expressed the highest level of dissatisfaction (36 per cent) with public transportation. A large proportion of these refugees (16 per cent) reported that public transportation does not even exist. Camp refugees in Lebanon and Jordan expressed lower levels of satisfaction compared to refugees in other locations, while, unexpectedly, West Bank refugees (83 per cent) were the most satisfied. Except for West Bank camp refugees, at least 20 per cent of refugees in all fields were dissatisfied with the public transportation in their neighbourhoods.

\subsection{Respiratory problems caused by the housing environment}

Respiratory problems may occur when toxic fumes generated within the housing environment are inhaled on a daily basis. Fuels such as coal, fuel wood, and kerosene may cause severe respiratory problems when ventilation or exhaust systems are inadequate. The availability of certain fuels depends on the supply networks and on household resources to install a cooking/heating system (stove, heater) and purchase the appropriate fuel supply. Underprivileged communities living in a designated environment (refugee camps, their periphery, or poor neighbourhoods) may lack access to safe fuels, leading to greater respiratory problems. Poor ventilation not only impedes the release of toxic fumes, it also increases humidity, which can be the cause of major respiratory problems such as asthma due to allergic reactions to fungi that thrive in a humid environment.

We transformed respiratory data from the survey to create a dependent variable for analysis in a logistic regression. A value of 1 was attributed if respiratory problems were observed in at least one household member, and a value of 0 was attributed if no household member suffered from such problems. We then retained six independent variables, and their effect on respiratory problems was tested. The variable, no kitchen, was created on the assumption that households without kitchens may lack appropriate exhausts, which may result in a greater 
risk of inhaling toxic fumes. The variable, no stove, was created on the assumption that households that lack conventional gas or electric ovens or stoves are more likely to burn biomass, which releases harmful fumes. The variable toxic heating was created to test whether households using kerosene, fuel wood, or coal as a source of heating may have more respiratory problems than those using central heating, diesel, electricity, or gas. Humidity, poor ventilation, and residential site (camploutside-camp) were other independent variables tested for their effect on respiratory problems.

The regression showed that the variables, humidity and no kitchen, were reported to have a rather stronger adverse effect on respiratory problems. The variable, poor ventilation, was also seen to have a strong effect in all sites and locations. The variable, toxic heating, was reported as having a weak effect in all fields, except in Syria where it was reported to have a strong negative effect. Residential site (camploutside camp) and poor ventilation were reported to have the strongest adverse effects in Syria and Lebanon, which are the two country locations with the highest statistical significance. However, the model performs poorly in other locations. Thus, any conclusions drawn should be tempered.

Results suggest that fuel wood could be the cause of the higher rate of respiratory problems in Lebanon. Although fuel wood is quite commonly used in the West Bank and Gaza, the milder winter and thus shorter exposure to its fumes may explain the lower rates of respiratory problems there. The large proportion of refugees in Jordan and Syria who use kerosene and diesel may indicate that central heating systems with adequate exhausts reduce the amount of respiratory problems.

\subsection{Substandard housing indicator}

The urban poor often lack access to community services such as undisrupted water supply, covered drains, and sewerage networks. Human exposure to sewage poses risks of water-borne diseases such as diarrhoea, gastro-enteritis, hepatitis A, dysentery, giardia, or, in more extreme cases, cholera, and polio. In addition to daily hygiene needs, low-income households depend on water to earn their living from laundry, washing, and other water-reliant jobs. When not supplied regularly through the community service network, water is trucked from unregulated sources at high cost. Hence, resorting to water of lower quality containing different levels of contamination is often the only alternative to satisfy daily water consumption needs, while increasing the risks of contracting gastrointestinal diseases.

Table 1 shows that, except for Jordan (outside camp) and the West Bank (camp), figures for houses not connected to a sewer are always below 10 percent. However, many refugees (Syria camp, 25 per cent; Gaza camp, 19 per cent) lack a connection to a water network, which may increase the risk to contract gastrointestinal diseases.

As discussed above, Palestinian refugees reported that the main sources of discomfort in their houses (above 30 per cent, regardless of the field or the location) were overcrowding, lack of public space, presence of humidity, and 


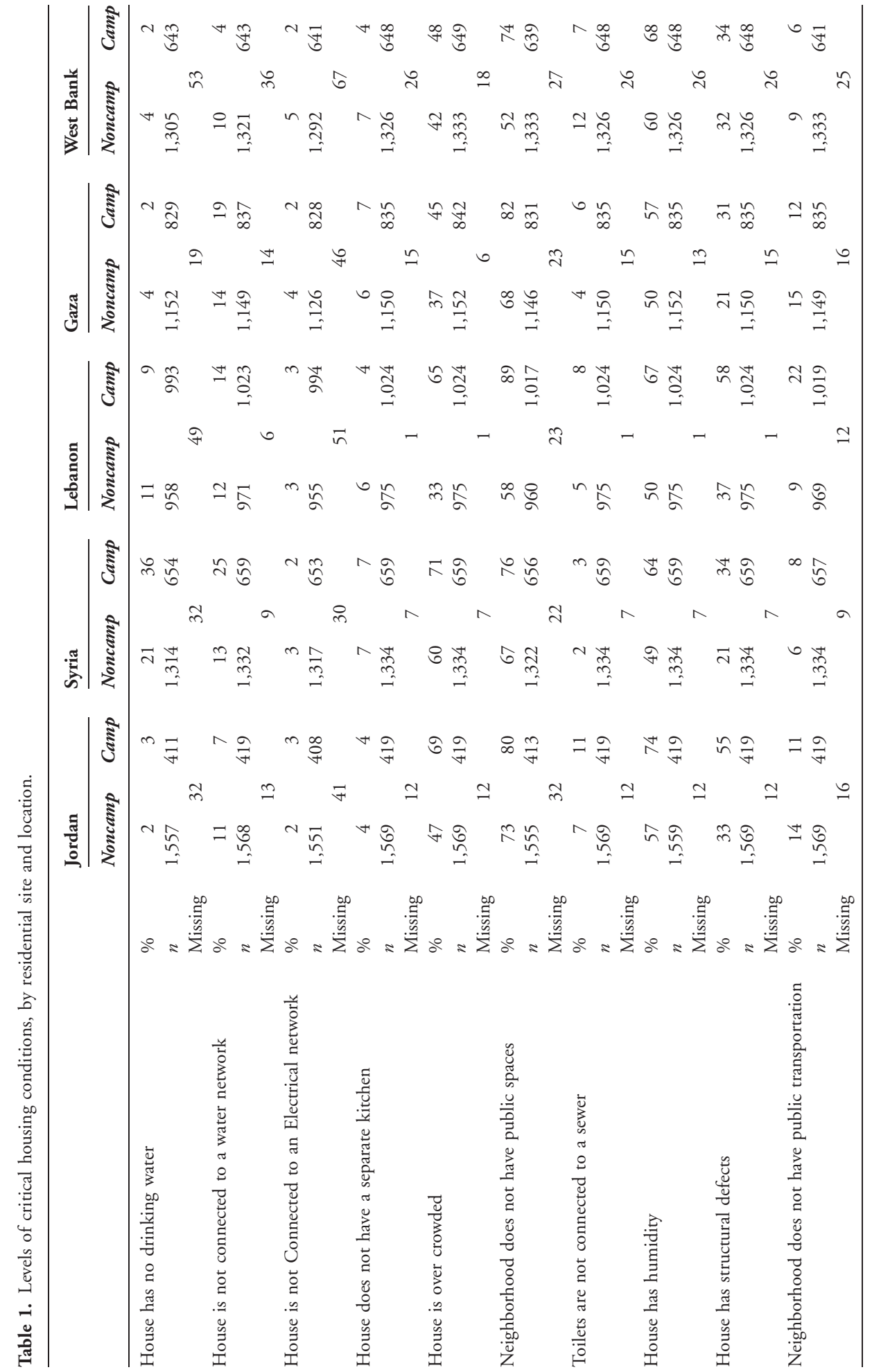


structural defects; all of which were substantially more important for houses within camps than outside camps.

\section{Conclusion}

The current housing situation of Palestinian refugees is the result of a "lasting" temporary status, and concomitant policies implemented by host governments and aid agencies.

The literature review presented in the first part of this contribution suggests that the poor housing condition of Palestinian refugees in all fields is due to three intertwined reasons. First, UNRWA has provided shelters to refugees without a mandate for conducting permanent re-housing programs, the status of refugees being provisional itself. Second, host governments have had different levels of restrictions for the development of refugee camps, especially in terms of construction and extension. In many cases, camps have been unable to extend vertically or horizontally, creating densification and critical overcrowding within houses. Third, camps have often remained isolated entities even when embedded in larger urban structures. Urban authorities have generally been unable to integrate camps in their municipal master plan. All necessary infrastructure, already available for cities, had thus to be thought out and constructed separately for camps. Having two separate urban infrastructures has often hindered efficient urban planning and management.

The statistical analysis performed on data collected in 2005 and presented in the second part of this study, confirms that Palestinian refugees registered with UNRWA have poor housing conditions. There is a sharp variation in housing conditions of refugees living in camps and outside camps in all locations: they are generally inferior in the camps compared to outside camps.

Overcrowding affects a large proportion of refugees in all locations. Those living in camps are proportionally much more likely to face overcrowding. Households larger than seven members and living in camps in Jordan and Syria are much more exposed to overcrowding than households elsewhere.

The population density of registered refugees is critical and comparable to, if not higher, than that of the densest administrative units in the world. Lebanon has the highest proportion of camps with a density superior to 100,000 persons/ $\mathrm{km}^{2}$, which makes it the most critical field in terms of camp density. This finding is consistent with the visible vertical extension of houses. The status of refugees and restrictions enforced by the host authorities seem to be the main reasons for the population density in camps.

The majority of refugees report a lack of recreational space and public spaces in their neighbourhoods. Houses in camps have more structural defects than those outside camps. A paved path leading to the front door of houses is found more often outside the camps than in camps. The situation in the camps in Lebanon is the worst, with a large majority of refugees lacking paved access to their respective residence. Refugees in camps in Lebanon also reported higher levels of dissatisfaction with the lack of public transportation close to their 
residence. Students endure lengthy commutes to their schools, regardless of the location of their residence.

The choice of energy, the quality of ventilation, and the occurrence of humidity in dwellings, have the strongest effects on respiratory problems, though in varying degrees at different locations. There seems to be a lower incidence of respiratory problems in Syria, possibly due to the use of diesel fuel as the main form of energy for heating. In other locations, on the other hand, the use of fuel wood tends to increase the incidence of respiratory problems.

According to these results, we foresee some prerequisites for improvement of the refugee housing in the camps. Host governments should have a greater flexibility in allowing refugee camps to be extended, assist aid agencies in the planning of these extensions, providing heavy infrastructure, and allow mobility and social integration of refugees. The housing situation could also be improved if low-cost housing solutions could be designed and implemented with the participation of the refugees themselves on the model developed by Arif Hasan for the Orangi Pilot Project. ${ }^{52}$ In this pilot project, stakeholders were not only receiving assistance but were organizing their own assistance, contributing to it, and remained critical towards any decision taken on their behalf. Furthermore, the implication of refugees in the design of houses developed a know-how, which generated numerous jobs for individuals in the community. Aid agencies assisting refugees should provide them also with the means to achieve the goals mentioned above and help them in setting up communitybased organizations oriented for housing improvement.

We also foresee the need for further investigation of the housing conditions of the Palestinian refugees. Additional qualitative housing research from both architects and social scientists, in the five fields where UNRWA operates, could help in understanding how refugees endure their housing conditions locally. It would allow highlighting differences between the fields, while understanding local housing problems, which could add to our statistical analysis across the fields. Such a research would also be of help in providing UNRWA with a tool to improve and adjust its services locally.

Another important field of investigation would be an analysis of urban patterns connecting urban camps with their larger urban environment. This type of research would allow optimizing municipal services and planning between the embedded entities. For this specific case, information extracted from a geographic information system analysis based on aerial photography would give important insights.

52 Op cit., fn. 9. 